NBER WORKING PAPER SERIES

\title{
HAS THE UNIFIED BUDGET UNDERMINED THE FEDERAL GOVERNMENT TRUST FUNDS?
}

\author{
Sita Nataraj \\ John B. Shoven \\ Working Paper 10953 \\ http://www.nber.org/papers/w10953
NATIONAL BUREAU OF ECONOMIC RESEARCH 1050 Massachusetts Avenue
Cambridge, MA 02138
December 2004

This paper was presented at a conference sponsored by the Office of Policy, Social Security Administration and the Michigan Retirement Research Consortium. The conference was titled "The Future of Social Security" and held at the National Press Club in Washington, D.C. on August 12-13, 2004. This research was supported by the U.S. Social Security Administration through grant \#10-P-98363-1 to the National Bureau of Economic Research as part of the SSA Retirement Research Consortium. The opinions and conclusions expressed are solely those of the author(s) and do not represent the opinions or policy of SSA, any agency of the Federal Government, or the NBER. The authors would like to thank Gopi Shah for superb research assistance, Peter Orszag for helpful comments and suggestions, and Kent Smetters for generously sharing his data and discussing this research. The views expressed herein are those of the author(s) and do not necessarily reflect the views of the National Bureau of Economic Research.

(C) 2004 by Sita Nataraj and John B. Shoven. All rights reserved. Short sections of text, not to exceed two paragraphs, may be quoted without explicit permission provided that full credit, including $(\odot$ notice, is given to the source. 
Has the Unified Budget Undermined the Federal Government Trust Funds?

Sita Nataraj and John B. Shoven

NBER Working Paper No. 10953

December 2004

JEL No. H0

\begin{abstract}
In order to ease the burden on workers during the retirement of the baby boom generation, the 1983 Social Security Reforms set payroll taxes above the level needed to pay current benefits, thus partially prefunding the baby boomers' retirement. The military and civil service retirement programs followed suit in the mid-1980s and switched from pay-as-you-go financing to funded systems. The excess income generated by these retirement programs was held in the federal trust funds, which have accumulated almost $\$ 3$ trillion since the reforms took place. However, this paper presents evidence that the trust fund build-up may not help future generations due to the adoption of the Unified Budget in 1970. The Unified Budget includes trust fund receipts as income and trust fund payments as expenditures. The empirical evidence suggests that attempts to balance the Unified Budget while the trust funds were generating surpluses has led to increased government spending and personal and corporation income tax cuts within the rest of the federal government. There is no evidence of increased government saving as a result of the trust fund accumulations. An alternate theory of increased national saving is also explored, where increased payroll taxes accompanied by decreased income taxes induces higher personal saving. This mechanism, suggested by Diamond, also does not appear to have significantly enhanced the wealth of future generations.
\end{abstract}

\author{
Sita Nataraj \\ Occidental College \\ snataraj@oxy.edu \\ John B. Shoven \\ NBER \\ 30 Alta Road \\ Stanford, CA 94305-8715 \\ and Stanford University \\ shoven@leland.stanford.edu
}




\section{Has the Unified Budget Undermined the Federal Government Trust Funds? by Sita Nataraj and John B. Shoven}

\section{Introduction}

The 1983 Social Security Reforms (sometimes referred to as the Greenspan Commission reforms) were the most sweeping in the almost 70 year history of the system. They were made under the threat of an almost immediate inability to pay full benefits to Social Security recipients (Schieber and Shoven, 1999). One of the key elements of the 1983 reforms involved setting the Social Security payroll tax rates above the level required to pay current benefits. That is, the Greenspan Commission's plan was for Social Security to depart from pay-as-you-go (PAYGO) financing and to partially prefund the retirement costs of the baby boom generation. The idea was to offer some relief to the workers in the 2015 to 2050 period in supporting the enormous retired population forecast for that period. By forcing workers in 1984-2015 to pay higher payroll taxes than required to finance current retirement benefits, the hope was that workers in the 2016-2050 era could pay lower than PAYGO taxes. The trust

fund buildup and subsequent spend down would spread the burden of the retirements of baby boomers over 65 years rather than 30 years and somewhat even out the tax burden faced by different generations of workers.

While Social Security represents the largest federal trust fund (the retirement and disability programs combined were estimated to hold $\$ 1.63$ trillion in assets at the end of fiscal 2004), the federal government also maintains trust funds for Medicare, unemployment insurance, civil service and military retirement, and transportation. The reform of Social Security financing during the 1980s was accompanied by a move towards funding the military and civil service retirement programs as well, again with the intent to relieve the tax burden 
on future generations. Overall, the annual surplus across all trust funds increased, in constant 2000 dollars, from $\$ 16.6$ billion in 1980 to $\$ 147.9$ billion in 1990 . Clearly, the 1980 s were a decade of change with respect to the operation of federal government trust funds. The biggest ones went from PAYGO financing to full or partial funding. As a result of the sustained surpluses of the trust funds, they accumulated almost $\$ 3$ trillion in assets between 1985 and 2004.

Despite this success in building up the assets of the trust funds, it is not at all obvious that the intended intergenerational burden sharing will take place. In order for the trust funds to actually assist future generations of workers, they must increase national saving, presumably by raising government saving. The only way to assist future workers is to leave them more wealth. However, current federal budget policies treat the surplus of trust fund revenues over expenditures, and the interest received by the trust funds, as part of the unified surplus. The focus on balancing the unified surplus may serve as an invitation for the rest of government (referred to as the federal funds) to offset the trust fund surplus through increased government spending and the reduction in other taxes. Thus, the budget process may undermine the attempt to raise government saving and build resources for future workers.

Alternatively, the increased payroll tax that accompanied the attempt to partially prefund Social Security, and to fund the military and civil service retirement programs, conceivably could increase national saving without increasing government saving. The mechanism for this was suggested by Diamond (2003). If the higher than PAYGO-required payroll tax permitted an offsetting reduction of the personal income tax (and perhaps the corporation income tax); the composition of tax revenues was changed. If the marginal propensity to save out of the payroll tax is low relative to the marginal propensity to save out 
of personal income taxes, then private saving might increase as the country moved to the new revenue mix. The idea is that the payroll tax is borne by relatively low income workers, at least in comparison to those who bear the personal income tax, and that these lower income workers have a marginal propensity to consume of approximately unity. The higher payroll taxes might not depress saving, whereas the lower personal and corporate income taxes could increase it.

This paper examines whether the shift from PAYGO to partially funded Social Security (and the corresponding shift in the funding of military and civil service retirement plans) resulted in a shift in national saving. We know that the attempt to partially prefund Social Security benefits and to fund military and civil service pensions will tend to enlarge the unified surplus numbers ceteris peribus. However, if the larger unified surplus projections permit additional government spending and tax reductions, the saving by the trust funds may be partially or even completely offset by reductions in federal funds saving. We also explore whether larger trust fund surpluses resulted in increased personal saving through the channel suggested by Diamond (2003).

Elmendorf and Liebman (2001), Smetters (2003), Burtless and Bosworth (2004), and Shoven (2003) examine related questions. Our methodology is most closely related to that of Smetters, who empirically demonstrates that increases in the off-budget (Social Security) surplus tends to be associated with reductions in the on-budget (non-Social Security) surplus. However, the Smetters study focuses only on Social Security surpluses: the surpluses of the other trust funds are included in the on-budget surplus. Burtless and Bosworth (2004) extend Smetters' analysis to other developed countries, as well as to state governments. We extend the analysis by examining the impact of increases in the aggregate surplus of all federal trust 
funds on saving by the rest of the government (the federal funds). We believe this is the appropriate way to address the question of whether the government's attempts to save via the trust funds have been successful. Since the assets in several trust funds were increased simultaneously during the 1980s, an analysis of on- and off-budget surpluses will tend to attribute the impact of the civilian and military retirement funds to the Social Security trust fund.

Our primary result is that increases in the aggregate surplus of the trust funds are offset - perhaps completely - by reductions in the federal funds surplus. In fact, using words that sound more familiar, the trust fund surpluses result in enlarged deficits for the rest of the government. We maintain that it is the existence of a unified budget that produces this offset. Again confirming Smetters' (2003) results, we show that prior to the adoption of a unified budget in 1970, an increase in the surplus of the trust funds did not reduce saving by the rest of the government. To hammer the point home, the government appears to have had the ability to save before the advent of the unified budget, but has lost that ability since. The $\$ 3$ trillion of assets in the trust funds represent the cumulated surpluses of their operations with interest. However, the money has been spent or returned to taxpayers and not saved, at least not by the federal government.

We also do not find empirical support for the Diamond hypothesis that increasing the payroll tax to build up the trust fund results in increased personal saving. While we believe that this argument is theoretically sound, we conclude that the effect is empirically negligible. Thus, efforts to build up the trust funds are at least partially offset (and quite likely completely offset) by reductions in government saving elsewhere, while having no discernable effect on personal saving. 
One implication of this argument is discussed by Bosworth and Burtless (2004): if the government is unable to increase saving by building up its trust funds, then a system of individual accounts for Social Security - rather than centralized investment of the trust fund in equities - is more likely to produce an increase in national saving (since individual accounts would not be included in the federal budget). However, our analysis suggests that individual accounts are not necessary to remedy the situation. All that is required is a shift in emphasis to the federal funds surplus as a measure of the government budget balance. This number is already calculated and reported; however, attempts to balance "the budget" have focused almost exclusively on the unified surplus.

This paper is organized as follows. Section II describes the history behind the adoption of the unified budget. Section III presents our econometric model and results pertaining to government saving. Section IV presents our empirical analysis of the relationship between trust fund surpluses and personal saving. Section V concludes.

\section{The Unified Budget: A Historical Perspective}

The unified budget was adopted in 1970 based on the recommendation of the 1967 President's Commission on Budget Concepts. The idea underlying the Commission's recommendation was that the unified budget provides the best measure of the macroeconomic impact of the public sector. Prior to 1970, three different measures of the budget surplus existed. One measure came from the National Income Accounts. The other two measures were derived from the administrative budget (which excluded the trust funds) and the consolidated cash budget (which included the trust funds). Fiscal policy tended to focus on the administrative budget. 
The goal of the President's Commission was to reconcile these various measures and arrive at an appropriate definition of the budget. Regarding the trust funds, the Commission argued: "The surplus or deficit in the administrative budget is a misleading guide for measuring the fiscal impact of the budget on the economy." (President's Commission 1967, p. 27) Thus, the Commission strongly recommended the use of a unified budget. Since 1970 the main policy focus has been on the unified budget surplus (Elmendorf and Liebman 2000), although federal funds surplus figures are also computed and published. The federal funds numbers tend to be buried in the fine print of the massive budget documents.

Prior to the 1980s, the important trust funds operated largely on a PAYGO basis. As a result, during this period, the choice of surplus measure - unified or federal funds - did not matter much. However, a $\$ 200$ billion per year gap between the federal funds and unified surplus measures has opened up since 1985 - that is, the annual federal funds deficit is now roughly $\$ 200$ billion larger than the unified deficit commonly emphasized (Shoven 2003). A widespread belief - based on the unified budget figures - is that the government ran large surpluses in 1998-2001. However, the federal funds budget has consistently run deficits since 1969 (the single exception being a very small $-\$ 1.8$ billion - surplus in 2000). Thus, the large surpluses of 1998-2001 were a result of federal funds deficits being hidden by the trust funds surpluses.

Conventional economic wisdom suggests that the government should attempt to balance the budget at full-employment. Attempts to implement this approach have tended to focus on the unified budget. For example, the Gramm-Rudman-Hollings Act, which attempted to force a reduction in the federal deficit during the 1980s, established targets for 
the unified budget only. Moreover, in public debate, references to "the surplus" typically mean the unified surplus. For example, according to a CNN story published in 2000:

The federal budget surplus for fiscal year 1999 was $\$ 122.7$ billion and $\$ 69.2$ billion for fiscal year 1998. Those back-to-back surpluses, the first since 1957, allowed the Treasury to pay down $\$ 138$ billion in national debt (Wallace 2000).

More accurately, however, the total federal debt did not fall in either 1998 or 1999 . The publicly held debt fell because the government was using the trust funds surpluses to finance its operations. This resulted in an increase in debt held by the trust funds, which more than offset the reduction in the publicly held debt. Which is the correct measure of the federal debt? As discussed by Shoven (2003), if the trust fund assets are to be viewed as "real" assets in any meaningful sense, then government debt held in the trust funds represents a real liability for taxpayers. That is, from an accounting perspective, the trust funds cannot be treated as assets by the programs they finance unless a corresponding liability is acknowledged. The unified surplus fails to acknowledge such a liability by treating the trust funds' net income as money that is available to spend on other programs or rebate to taxpayers.

In addition to its recommendation of a unified budget, the Commission also emphasized the importance of issuing separate reports of the trust fund finances side-by-side with the unified budget:

In many instances, in fact, [the Commission] sees merit in earmarking specific revenue sources for well-defined programs of a long-run character. The need to respect the integrity of trust funds, and the requirements of control and accountability, in turn require the continued availability of trust fund receipt and expenditure figures separate from those of other funds. (President's Commission 1967, p. 27)

Thus, the Commission allowed for the continued earmarking of funds for Social Security and other programs. An important question is whether such earmarking matters in any real sense. 
Earmarked funds can be spent by the Treasury without explicit authorization (CBO 2002). In a political economy framework, the earmarking of funds does matter (see, e.g., Bos 2000, Marsiliani and Renstrom 2000), and we would certainly expect the buildup of the trust funds to have real effects on the government's spending priorities. However, the question with which this paper is concerned is whether, in the aggregate, the trust funds can be used as a vehicle for government saving; if so, then the buildup in the trust funds during the 1980s can achieve its purpose of relieving the burden on future generations.

Smetters (2003) provides a useful summary of the various perspectives on this issue with regard to the Social Security trust fund. The key criterion for determining whether the trust funds represent a real government asset is whether an increase in the trust funds results in a lower level of publicly held debt than there would have been otherwise. If so, they represent real saving. Smetters finds empirical support for the perspective that the focus on the unified budget invites the government to increase its non-Social Security spending whenever the Social Security surplus increases.

We agree with this perspective, and we extend Smetters' analysis to include all the trust funds. Attempts to save in the trust funds treat the trust funds as real government assets. But this is inconsistent with the use of a unified budget because the unified surplus treats the trust funds surplus as money that is currently available to spend, rather than money that has been earmarked for saving. The picture that emerges from our empirical analysis is that the trust funds surpluses during the 1980s gave the government more flexibility to increase other spending and cut taxes while still meeting Gramm-Rudman-Hollings, or other unified budget deficit targets. In other words, when the government focuses on balancing the unified budget, attempts to save in the trust funds are undermined. The higher than necessary payroll taxes 
permit more spending and lower rates on other taxes, but they do not make future generations wealthier.

\section{Econometric Analysis}

We use macroeconomic time-series data from 1949-2003 to estimate the relationship between the surpluses in the trust funds and federal funds. Our dataset excludes the transition quarter in 1976-77 when the government changed the fiscal year. Our current-dollar trust fund and federal funds surplus data come from Historical Table 1.4 of the FY 2005 Budget of the U.S. Government; we convert these into constant (2000) dollars using the GDP deflator. Figure 1 shows the real trust funds and federal funds surpluses from 1949 through 2009, with the 200409 figures being the OMB projections from the 2005 U.S. Budget. It is clear from the figure that increasing trust fund surpluses during the 1980s were accompanied by larger federal funds deficits.

In order to determine whether this relationship holds up under formal econometric analysis, we estimate the following equation:

$$
\text { FFSURP }_{t}=\alpha+\beta \cdot \text { TFSURP }_{t}+\gamma \cdot X_{t}+\varepsilon_{t}
$$

where

$F F S U R P_{t}=$ Real Federal Funds surplus in year $\mathrm{t}$

$\operatorname{TFSURP}_{t}=$ Real Trust Fund surplus in year $\mathrm{t}$.

$X_{t}=\mathrm{a}$ vector of control variables.

$\varepsilon_{t}=$ an independent, identically distributed error term.

In the regressions, we consider two alternative specifications of TFSURP and FFSURP. First, we use the standard surplus measures discussed above and depicted in Figure 
1. The standard measures count as trust fund revenue interest credited on the special-issue government bonds held in the trust fund. The interest is paid by simply issuing more bonds to the trust funds. These interest payments are treated as an expenditure in computing the federal funds surplus. However, as discussed by Smetters (2003), this treatment of interest payments may not be appropriate. The underlying theory suggests that if the trust funds earn additional income from an excess of contributions over expenditures, this income is then spent by the rest of the government. This argument does not, however, apply to interest income the trust funds receive from the rest of the government. To address this issue, we proceed analogously to Smetters and construct "modified" trust funds and federal funds surpluses. The modified trust funds surplus is computed by subtracting interest received on trust fund assets from our previous measure of the trust funds surplus; these interest payments are then added to our previous measure of the federal funds surplus to obtain the modified federal funds surplus. ${ }^{1}$ Both surplus measures are divided by real potential GDP in order to reduce the possibility of heteroscedasticity.

The coefficient of interest is $\beta$. If $\beta$ is close to 0 , this suggests that the government's attempts to save in the trust funds have been successful: an increase in trust fund saving does not affect saving by the rest of the government. On the other hand, if $\beta$ is negative, an increase in trust fund saving is offset by dissaving by the rest of the government; in particular, if $\beta=-1$, then an increase in trust fund saving has no impact on overall government saving. This econometric model is analogous to that of Smetters (2003), who estimates the relationship between the surplus in the Social Security trust fund and the surplus in the rest of the budget (including the other trust funds).

\footnotetext{
${ }^{1}$ The interest payment data were provided by Bob Kilpatrick of the Office of Management and Budget on May
} 
Our control variables include the ratio of actual to potential GDP, the ratios of real capped and uncapped wages to potential GDP, the nominal interest rate paid on the specialissue Treasury bonds held by the Social Security trust fund, and a quadratic time trend. Our potential GDP data come from January 2004 Congressional Budget Office calculations, and take into account factors such as the potential labor force and potential total factor productivity. The potential GDP measure is adjusted for inflation using a factor provided by the CBO; the actual GDP measure is adjusted for inflation using the GDP deflator. The ratio controls for the fact that business cycle fluctuations are likely to have an impact on both the federal funds and the trust funds surpluses.

The capped wage measure comes from the Social Security Administrations' Annual Statistical Supplement (Table 4.B1), and the uncapped wage measure from the National Income and Product Accounts (Table 2.1). We adjust both measures for inflation using the GDP deflator. Capped wages are not available for 1949 and 2003, so we impute these amounts by assuming that the ratio of capped to uncapped wages was the same as in the adjacent year. These two variables are intended to capture the impact of a mean-preserving spread in wages on Social Security payroll tax receipts. Since the payroll tax is regressive, a mean-preserving spread in wages is likely to reduce the trust funds surplus by lowering payroll tax revenue; it is also likely to increase the federal funds surplus through the progressive income tax. Therefore, omitting these two variables might lead to a downward bias in the estimate of $\beta$.

The nominal special-issue interest rate data are from the Social Security Administration. In each year, this variable is computed as the average of the 12 monthly interest rates on new issues during the year. Including this variable is important for the 
specifications that use the standard surplus measure. Because interest payments flow from the federal funds to the trust funds, an increase in the nominal interest rate will increase the standard measure of the trust funds surplus and reduce the standard measure of the federal funds surplus. Therefore, the omission of this variable will tend to bias $\beta$ downwards. Since this issue does not arise with the modified surplus measures, the interest rate variable is not included in these specifications. ${ }^{2}$

For each specification, we test for heteroscedasticity using the Breush-Pagan score test against multiplicative heteroscedasticity. We also test for serial correlation in the error terms using Durbin's alternative test, in which the residuals from the original regression are regressed on their lagged values (up to three lags) and all the independent variables. The pvalue for each of these tests (against the null hypothesis of no serial correlation or heteroscedasticity) is reported in the results table for each specification. Our tests indicate evidence of heteroscedasticity and first or second order serial correlation in several of the specifications. The reader should note, however, that our test for heteroscedasticity is not robust to the presence of serial correlation; thus, the heteroscedasticity test results may not be valid for the specifications in which serial correlation is present. On the other hand, our serial correlation test results are robust to heteroscedasticity because we use a heteroscedasticityrobust estimate of the variance-covariance matrix for the test equations. ${ }^{3}$ To address the potential presence of heteroscedasticity and serial correlation, we report Newey-West standard errors with a lag of two periods. ${ }^{4}$

\footnotetext{
${ }^{2}$ We thank Peter Orszag for suggesting the last two points about the capped and uncapped wages, and the nominal interest rate.

${ }^{3}$ See Wooldridge 2002, Chapter 12, for a discussion of this issue.

${ }^{4}$ One guideline for determining the lag for computing Newey-West standard errors is the integer portion of $n^{\frac{1}{4}}$, where $n$ is the sample size (see Wooldrige 2002, p. 397). In our case, this guideline implies a lag of two periods.
} 
Our baseline results are reported in Table 1. In all of our specifications, the coefficient on the trust funds surplus variable is negative and statistically significant at the 5 percent level. Adding covered and uncovered wages does lower the magnitude of the coefficient, but by a relatively small amount. The coefficient on the nominal interest rate is positive (unexpectedly) but not statistically significant; its inclusion barely changes the coefficient on the trust funds surplus. Our preferred specifications are the ones that include the full set of controls (the last two columns in the table); even though the interest rate coefficient has an unexpected sign and is not statistically significant, we believe that theory strongly supports its inclusion in the standard surplus measure regression. These specifications suggest that a $\$ 1$ increase in the trust funds surplus reduces the federal funds surplus by $\$ 1.54$ (for the standard measures) or $\$ 1.44$ (for the modified measures). Both estimates are significantly different from zero and not significantly different from 1. A 95 percent confidence interval for the magnitude of the coefficient is .56 to 2.53 for the standard measures and .49 and 2.41 for the modified measures. Even the lower end of both confidence intervals implies an offset that is economically significant. Thus, our results suggest that an increase in government saving via the trust funds is at least partially - and perhaps completely - offset by a decrease in government saving outside of the trust funds.

It is worth mentioning that our point estimates of the coefficient on the trust fund variable differ considerably from those obtained by Smetters (2003). Smetters estimates that a $\$ 1$ increase in the Social Security surplus reduces the on-budget surplus by $\$ 2.76$; this estimate is statistically greater than 1 , implying that an increase in off-budget saving actually reduces overall government saving. A possible explanation for this difference is that the government attempted to build up several trust funds simultaneously during the 1980s. Thus, 
the coefficient of the off-budget surplus is likely to pick up some of the impact of the other trust funds.

As discussed above, the unified budget was adopted in 1970. We have argued that it is the focus on balancing the unified budget that gives rise to the government's inability to save in the trust funds. Thus, it is reasonable to split our time series into two periods - 19491969 and 1970-2003 - and re-run our regressions. Theory predicts that the coefficient of the trust funds surplus variable should be close to zero prior to the adoption of the unified budget and negative afterwards. The split-sample regression results are reported in tables 2 and 3.

As can be seen from Tables 2 and 3, the estimate of $\beta$ over the 1970-2003 period is negative and statistically significant; in this case, it is also significantly greater than 1 in magnitude. However, in the pre-1970 period, the point estimates of $\beta$ are not significantly different from zero. This confirms our argument that the adoption of the unified surplus is the factor that hinders the government's ability to save in the trust funds. Smetters (2003) finds the same qualitative result (no relationship pre-1970 and an inverse relationship post-1970) for the on- and off-budget surpluses.

Overall, our results suggest that government saving has not increased despite the almost $\$ 3$ trillion accumulated in trust funds since 1985. Future generations may have lower payroll taxes than they otherwise would have, but they will not have more resources. They themselves will have to finance their lower payroll taxes with higher income taxes (or lower government spending). The intergenerational burden sharing envisioned by the Greenspan Commission has been thwarted.

Similar results emerge from cross country analysis. Bosworth and Burtless (2004) estimate similar regressions for OECD countries and show that increases in Social Security 
trust fund surpluses are at least partially offset by reduced surpluses in the rest of the government. Since these countries use unified budgets, this result is as expected. Bosworth and Burtless also show that at the state level in the U.S., surpluses in employees' retirement trust funds are not offset by reductions in saving by the rest of the government. One explanation they propose is that, unlike national governments, state governments use a system of accrual accounting under which pension funds are kept separate from the rest of the budget.

The issue regarding whether the unified budget affected the legitimacy of the trust funds can be looked at another way. Consider a counterfactual situation where the excess payroll tax receipts were used to fund individual accounts rather than to purchase government bonds. In fact, to make the two cases almost identical, consider what would happen if the individual accounts were $100 \%$ invested in U.S. government bonds. At first glance, the money available to the rest of the government would be unchanged. However, the funding of individual accounts would almost certainly be treated as an expense. The interest payments on the government bonds in the individual accounts would also be treated as an expense. The budget surplus would be lower by the amount of the cash flow surplus in social security and the other trust funds (the new deposits into accounts) and the interest payments received on existing bonds. That is, the surplus would have switched from what we now calculate as the unified surplus to the much lower federal funds surplus. The saving in individual accounts would not be treated as part of the surplus and thus less likely spent by the rest of government. However, this accounting change could be adopted without individual accounts; what would be required is separating the trust fund accounts from the rest of the budget and reporting the federal funds budget as the primary assessment of the government budget and the target for balancing at full employment. 


\section{Trust Fund Accumulations and Personal Saving}

As discussed above, an increase in the trust funds surplus can raise national saving by raising personal saving (Diamond 2003). According to this argument, increases in the (regressive) payroll tax disproportionately affect low-income individuals, who tend to be liquidity constrained. To the extent that the resulting trust funds surpluses are used to finance income or other tax cuts, which disproportionately affect non-liquidity higher-income individuals, they will tend to raise personal saving. This follows from the fact that higherincome individuals - who tend not to be liquidity constrained - have a higher marginal propensity to save out of disposable income than the liquidity-constrained poor. Historically, most of the increases in the trust funds have resulted from increases in the payroll tax. Thus, to test for the "Diamond effect," we regress the National Income and Product Accounts measure of personal saving on the trust funds surpluses and our other macroeconomic control variables. The results from various specifications of this regression are reported in Table 4 .

The specifications that include all the controls suggest that a $\$ 1$ increase in the trust funds surplus may increase personal saving by between 56 and 66 cents. However, the relevant coefficient is only statistically significant at the 5 percent level when using the modified trust funds surplus measure. Given the sensitivity of the coefficient estimate across our specifications, we conclude that we do not see strong evidence for the economic significance of the Diamond effect. 


\section{Conclusions}

The issues that this paper deals with are clearly important. The primary issue is whether the assets in the federal trust funds will help future generations of workers finance the retirements of the baby boom generation. Has the governmental policy of building up these trust funds succeeded in transferring resources to the next generation of workers? Unfortunately, the evidence of this paper suggests that the answer is "no." Our empirical analysis is consistent with the idea that the focus on the unified federal budget has undermined the wealth accumulation aspect of the trust funds. The surplus revenues that the trust funds have turned over to the rest of the government have been spent and not saved. As a result, no extra wealth has been accumulated.

If the focus had been on balancing the federal funds budget instead of the unified budget and if the government had been equally successful with that balancing, the total debt of the government and the publicly held debt would have been $\$ 3$ trillion lower. Future generations would have been $\$ 3$ trillion wealthier and the vision of the Greenspan Commission would have been at least partially fulfilled. Of course, the focusing on the federal funds budget would have revealed a number of things. First, the large surpluses that we enjoyed in 1998-2000 never really existed, at least according to the federal funds accounts. Second, the 2004 budget deficit is roughly \$200 billion higher than reported and, third, the tax cuts, which may have been necessary for business cycle reasons, were not merely a rebate of sizable surpluses.

There is considerable debate as to whether the crisis in the financing of Social Security occurs in roughly 2017 when payroll tax receipts are insufficient to finance benefits or in the 2040s when the Social Security trust funds are projected to be exhausted. From the 
perspective of Social Security, the trust fund does represent real claims on the rest of the government. Thus, the presence of the trust fund may prolong the life of Social Security beyond the date at which tax receipts fall short of benefits payments. However, from the perspective of future generations of workers, the trust funds do not represent incremental wealth. Even if Social Security's life is lengthened, workers 15 years from now will have to pay off the obligations in the trust fund through increases in other taxes and cuts in other government services. The trust funds themselves do not provide any assistance to future generations of workers in coping with the inadequate income of Social Security to pay the legislated benefits. 
Figure 1: Real Trust Funds and Federal Funds Surpluses, 1949-2003

Estimated Real Trust Funds and Federal Funds Surpluses, 2004-2009

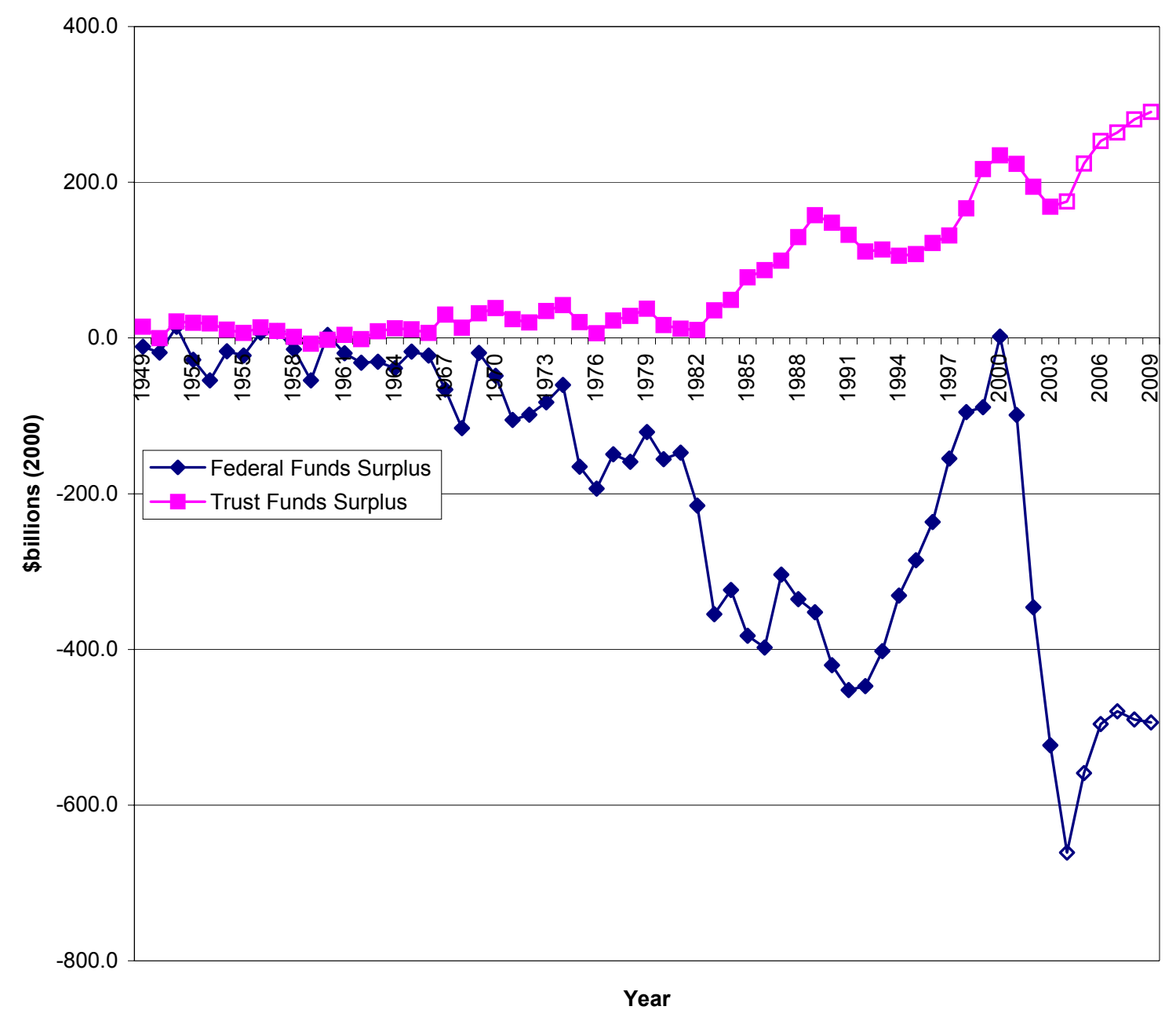


Table 1: 1949-2003

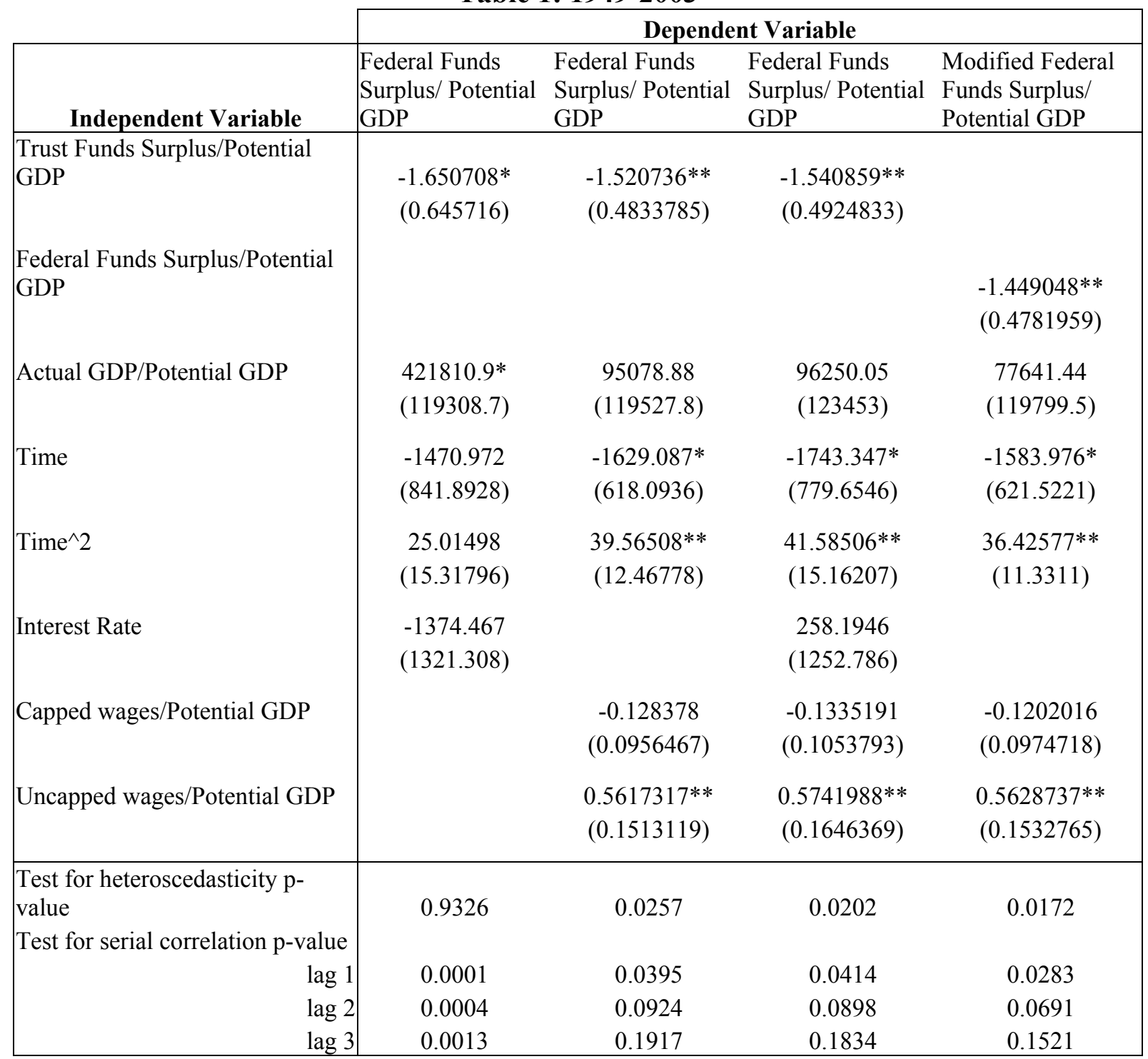

Notes: - Newey-West standard errors in parentheses. Test for heteroscedasticity is a Breush-Pagan score test against multiplicative heteroscedasticity. The null hypothesis is that there is no heteroscedasticity. Test for serial correlation is Durbin's alternative test, using a heteroscedasticity-robust variance-covariance matrix. Newey-West standard errors were computed with a maximum lag of 2.

* coefficient is significant at $5 \%$ level.

$* *$ coefficient is significant at $1 \%$ level. 
Table 2: 1949-1967

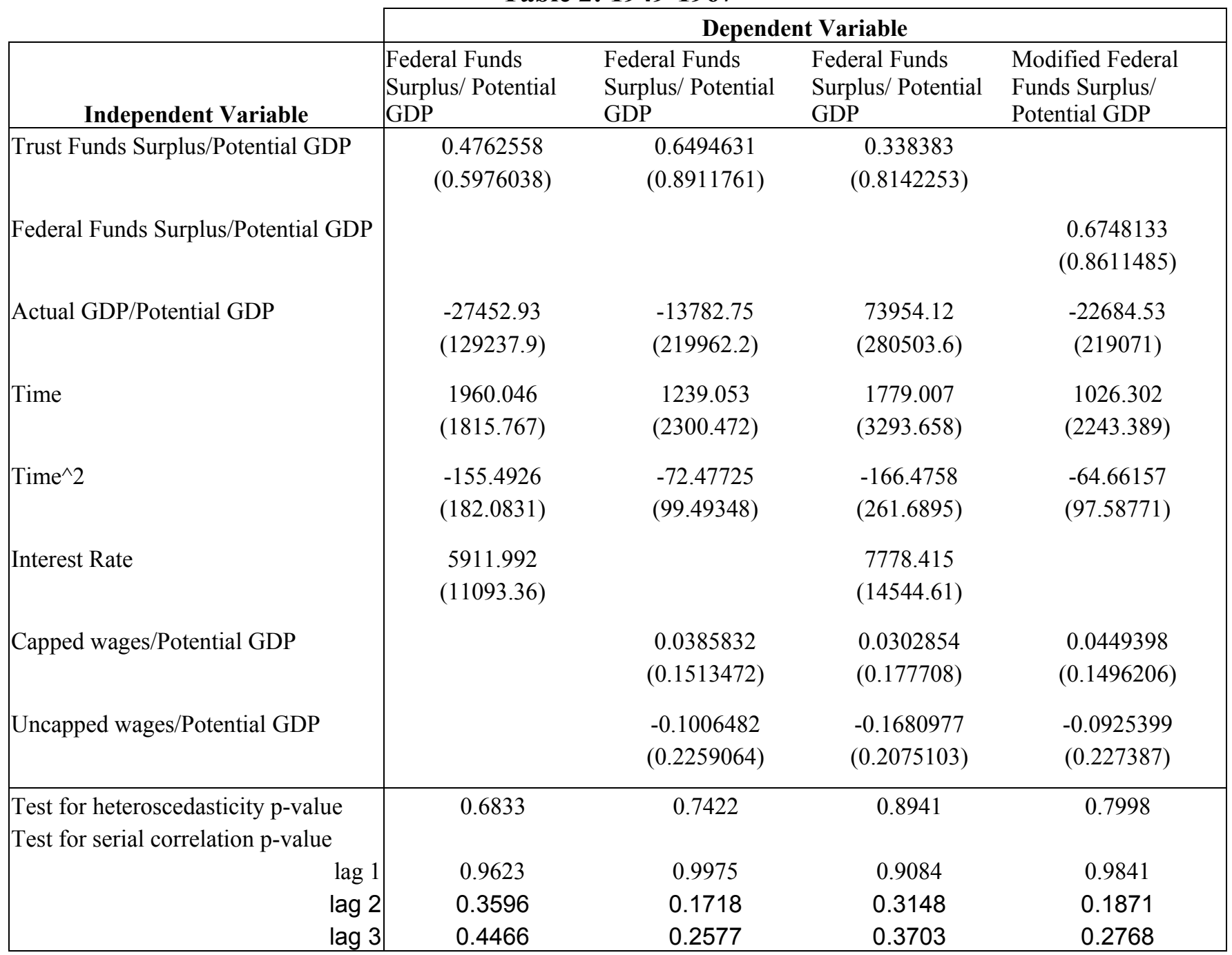

Notes: - Newey-West standard errors in parentheses. Test for heteroscedasticity is a Breush-Pagan score test against multiplicative heteroscedasticity. The null hypothesis is that there is no heteroscedasticity. Test for serial correlation is Durbin's alternative test, using a heteroscedasticity-robust variance-covariance matrix. Newey-West standard errors were computed with a maximum lag of 2.

$*$ coefficient is significant at $5 \%$ level.

$* *$ coefficient is significant at $1 \%$ level. 
Table 3: 1970-2003

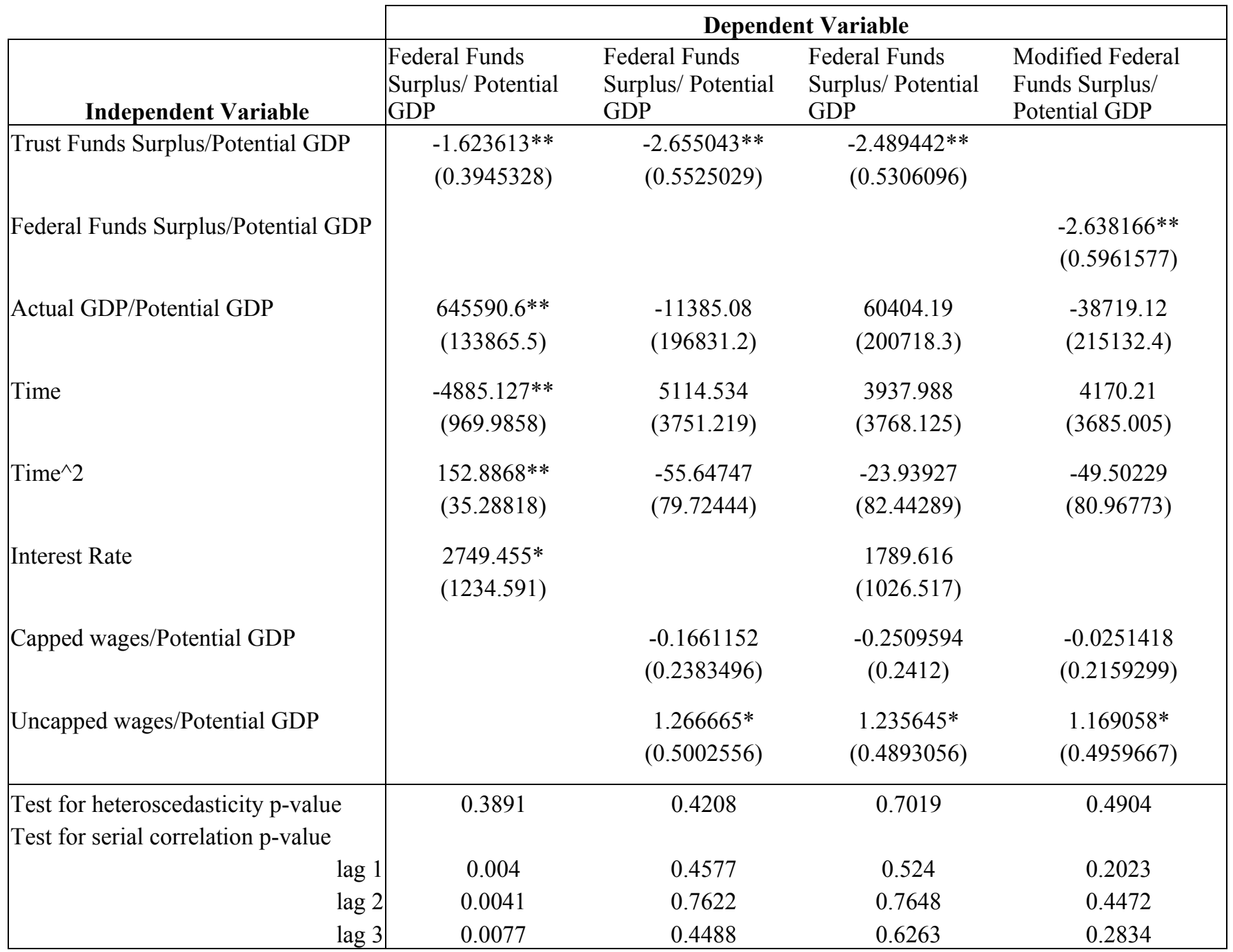

Notes: - Newey-West standard errors in parentheses. Test for heteroscedasticity is a Breush-Pagan score test against multiplicative heteroscedasticity. The null hypothesis is that there is no heteroscedasticity. Test for serial correlation is Durbin's alternative test, using a heteroscedasticity-robust variance-covariance matrix. Newey-West standard errors were computed with a maximum lag of 2.

* coefficient is significant at $5 \%$ level.

$* *$ coefficient is significant at $1 \%$ level. 
Table 4: Personal Savings Regressions, 1949-2003

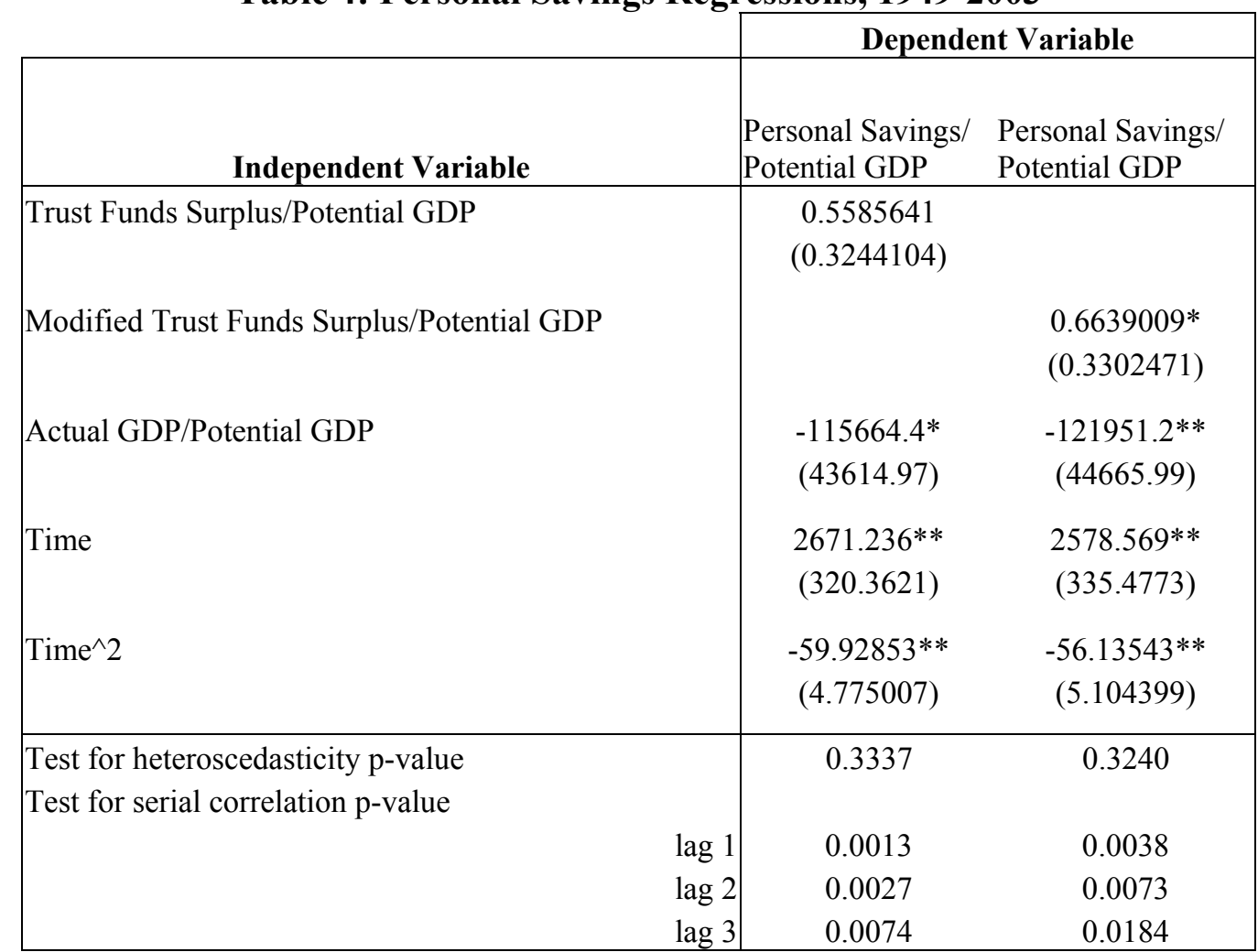

Notes: - Newey-West standard errors in parentheses. OLS standard errors in brackets. Test for heteroscedasticity is a Breush-Pagan score test against multiplicative heteroscedasticity. The null hypothesis is that there is no heteroscedasticity. Test for serial correlation is Durbin's alternative test, using a heteroscedasticity-robust variance-covariance matrix. Newey-West standard errors were computed with a maximum lag of 2 .

* coefficient is significant at 5\% (using Newey-West standard errors).

$* *$ coefficient is significant at $1 \%$ (using Newey-West standard errors). 


\section{References}

Bosworth, Barry and Gary Burtless, "Pension Reform and Saving," unpublished mimeo, January 5, 2004.

Bos, Dieter, “Earmarked Taxation: Welfare versus Political Support,” Journal of Public Economics, 75(3), March 2000, pp. 439-62

Diamond, Peter, "Social Security, the Government Budget and National Savings," unpublished mimeo, MIT, March 24, 2003.

Elmendorf, Douglas W. and Jeffrey B. Liebman, "Social Security Reform and National Saving in an Era of Budget Surpluses," Brookings Papers on Economic Activity, Volume 2, 2000, pp. 1-71

International Monetary Fund, Government Finance Statistics Manual, 2001.

Marsiliani, Laura and Thomas I. Renstrom, “Time Inconsistency in Environmental Policy: Tax Earmarking as a Commitment Solution,” Economic Journal, 110(462), March 2000, pp. C123-38.

Report of the President's Commission on Budget Concepts, Washington, DC: U.S. Government Printing Office, October 1967.

Schieber, Sylvester J. and John B. Shoven, The Real Deal: The History and Future of Social Security, New Haven and London,: Yale University Press, 1999.

Shoven, John B., "If the Trust Funds Are Real, the Surplus Numbers are Wrong," paper presented at the SIEPR Conference on U.S. Budget Policy and Practice, Washington, DC, May 8, 2003.

Smetters, Kent, "Is the Social Security Trust Fund Worth Anything?" unpublished mimeo, June 2003. 
Wallace, Kelly, "President Clinton Announces Another Record Budget Surplus," CNN.com, September 27, 2000, available at http://www.cnn.com/2000/ALLPOLITICS/stories/09/27/clinton.surplus/.

Wooldridge, Jeffrey M., Introductory Econometrics, Australia: South-Western College Publishing, 1999. 